\title{
Nutrient limitations, microbial food webs, and ‘biological C-pumps': suggested interactions in a P-limited Mediterranean
}

\author{
T. Frede Thingstad ${ }^{1}$, Fereidoun Rassoulzadegan ${ }^{2}$ \\ ${ }^{1}$ Department of Microbiology, University of Bergen, Jahnebakken 5, N-5020 Bergen, Norway \\ ${ }^{2}$ Station Zoologique, BP 28, F-06230 Villefranche-sur-Mer, France
}

\begin{abstract}
In light of evidence suggesting that both phytoplankton and bacteria in the Mediterranean Sea are limited by the availability of phosphorus rather than of nitrogen, and that most of the $\mathrm{P}$ in the photic zone during summer stratification exists as dissolved organic compounds (DOP), we address the question of how these observations may interact with the 'biological pump' transporting carbon to deep waters. From theoretical considerations, the $\mathrm{C}$ storage via sinking particles should function better in a P-than in an N-limited system. It is argued, however, that the microbial food web during summer stratification has a net accumulation of dissolved organic carbon (DOC) and DOP. The limited data available suggest a high DOC:DOP value which would make downwards transport of DOC with winter deep water formation a potentially effective mechanism in $\mathrm{C}$ sequestration from the atmosphere. Part of the DOC accumulating in the photic zone appears to be readily biodegradable. This is in conflict with a simple model of phytoplankton-bacterial competition for phosphate since phytoplankton, as an inferior competitor, would be expected to be reduced in biomass until autochthonous production of organic $\mathrm{C}$ falls to a level where bacteria become $\mathrm{C}$-limited. The conflict is resolved by including microzooplankton grazing as a controlling factor of bacterial biomass.
\end{abstract}

KEY WORDS: Phosphorus limitation - Microbial food webs · Carbon cycles · Marine biogeochemistry

\section{P-LIMITATION IN THE MEDITERRANEAN SEA?}

Considering (1) that the ratio of available nitrogen to phosphate in the western Atlantic seems to be close to the Redfield ratio of 16 (Richards 1958), and (2) that P seems to be more rapidly recycled than N (Bishop et al. 1977, Martin et al. 1979, Garber 1984), a mechanism suggested to lead to development towards $\mathrm{N}$-limitation in recycling ecosystems (McGill 1965, Hickel et al. 1993), one might be led to expect that $\mathrm{N}$-limitation of primary production during summer stratification of the Mediterranean should increase as nutrient-depleted surface water imported through the Straits of Gibraltar is transported eastwards. Contrary to such specula- tions, there are several references suggesting that the relationships between $\mathrm{P}$ and $\mathrm{N}$ are special in the Mediterranean Sea with larger probabilities of $\mathrm{P}$ becoming limiting for primary production than usually observed in true marine systems. Berland et al. (1980) reviewed the available evidence and concluded that the Mediterranean seemed to be peculiar in having $\mathrm{P}$ as the most limiting factor for primary production. More recently, Krom et al. (1991) measured the remaining concentrations of inorganic nutrients and found as a general trend an increasing N:P ratio eastwards in the Mediterranean. On the basis of high inorganic N:P ratios, the Adriatic Sea has also been considered to be P-limited (Vukadin \& Stojanski 1976), while 
McGill (1965), in a set of very variable N:P ratios, found high values in the Ionian and Ligurian Seas. Nutrient enrichment studies in the northwestern Mediterranean support this general impression of a predominance of P-limitation (Jacques et al. 1973, Fiala et al. 1976) but $\mathrm{N}$ and iron were found to play a role in parts of the year. In contrast to this, Owens et al. (1989) concluded that $\mathrm{N}$-limitation was more probable than P-limitation in the western part. Coastal areas heavily influenced by freshwater such as the northern Baltic (Lignell et al. 1992) and Norwegian fjords (Thingstad et al. 1993), or by freshwater seasonally carrying large concentrations of nitrate from farmland runoff such as those off the North Sea coast of the European continent (Hickel et al. 1993), may become $\mathrm{P}$ - rather than $\mathrm{N}$-limited. In the Mediterranean Sea with its relatively low freshwater input and high salinity, P-limitation is difficult to explain as a consequence of freshwater influence. Since nitrate:phosphate ratios in the Mediterranean deep waters are above the Redfield ratio, and apparently have been so since early measurements (McGill 1965), neither redistribution mechanisms within the water column, nor recent changes in human influence such as P-removal from sewage, seem to offer explanations to the observed P-limitation in the surface layer. Other mechanisms such as fast $\mathrm{N}$ fixation rates in coastal areas (Bethoux \& Copin-Montegut 1986, Bethoux et al. 1992) or selective phosphate precipitation due to input of iron-containing dust from the Sahara (Krom et al. 1991) have been suggested.

The question of a possible P-limitation in the western part has recently been examined more closely through investigations in Villefranche Bay on the French Mediterranean coast. Zweifel et al. (1993) demonstrated how orthophosphate addition would stimulate bacterial growth and degradation of naturally occurring dissolved organic carbon (DOC) in filtered $(0.2 \mu \mathrm{m})$ seawater reinoculated with bacteria. Also, orthophosphate addition seemingly stimulates DNA synthesis in the native Synechococcus population (D. Vaulot pers. comm.). Other evidence such as high alkaline phosphatase activity, short orthophosphate turnover times, and a significant 'luxury consumption' in both the bacterial and phytoplankton dominated size-fractions (Thingstad et al. unpubl.), all uniformly supports the impression that both bacteria and phytoplankton experience what might be called a 'physiological P-limitation' (Paasche \& Erga 1988).

\section{EQUILIBRIUM CONDITIONS FOR THE PHOTIC ZONE FOOD WEB}

Some physiological processes such as orthophosphate uptake far in excess of immediate growth re- quirements (Sakshaug \& Holm-Hansen 1977, Parslow et al. 1984) and induction of enzymes such as alkaline phosphatase (Perry 1972), may be taken as indicators of a P-starvation of the individual cells. If this starvation is strong enough to block processes essential for growth such as DNA synthesis, one could speak of a 'physiological' P-limitation. Such 'physiological' nutrient limitation is closely linked to, but not identical to, what might be called a 'systemic' nutrient limitation (Paasche \& Erga 1988). 'Systemic' nutrient limitation would be the limitation on total biomass in the system caused by the restricted amount of nucleic acids, proteins or other essential cell components which can be formed on the restricted amount of the nutrient available. This type of limitation would be demonstrated by a (temporary or permanent) increase in biomass following an addition of the limiting nutrient to the system. The importance of such a distinction in terminology may be illustrated by considering the paradoxical situation that phytoplankton in oligotrophic environments sometimes seem to grow at near-maximum growth rates (Goldman et al. 1979). If, in accordance with expectations, such an oligotrophic system responds to added nutrients by an increase in biomass, it would seem to be an example of 'systemic limitation' occurring without any appreciable 'physiological limitation'. Apparently (and interestingly), the implication of the observed 'physiological limitation' in Villefranche Bay surface waters is that this environment does not seem to conform to the Goldman paradox. The coupling between 'physiological' and 'systemic' P-limitations may be illustrated by simple food chain models of the type analyzed by Thingstad \& Sakshaug (1990) who suggested a model in which low total concentration (sum in all biological and biologically available pools) of the limiting nutrient in the photic zone would correspond to a food chain based on primary nutrient uptake in small-sized organisms, few predator levels with inefficient recycling, and a strong 'physiological' limitation of the organisms doing the primary uptake. Increased total concentration of available nutrient would shift the equilibrium towards more predator steps with more recycling and less 'physiological' nutrient limitation at the bottom of the food chain and, at sufficiently high total nutrient concentration, to the introduction of larger primary producers. Within such a framework, the signs of 'physiological' P-limitation at the bottom of the food chain as found in Villefranche Bay could be interpreted as signs of low concentration of biologically available total $\mathrm{P}$, and therefore a short food chain where regeneration does not satisfy the P-requirements of the standing stock of phytoplankton and bacteria.

In an open system such as the oceanic photic zone, there is of course the extra equilibrium condition of 
nutrient import ('new' production) equilibrating export when integrated over sufficient time (Dugdale \& Goering 1967). As a corollary to this: the food chain has to adjust to a structure and length (number of trophic levels) where the interacting organisms produce a loss equal to the input (Thingstad \& Sakshaug 1990). Sources of inputs of 'new' nutrients to a system with P-limitation may differ from that in N-limited systems where atmospheric input of $\mathrm{N}$ (Dahl et al. 1987, Bethoux et al. 1992) and N fixation (Bethoux \& CopinMontegut 1986, Codispoti 1989) may provide additional sources.

Small organisms have been suggested to have a lower $\mathrm{N}: \mathrm{P}$ ratio possibly due to a higher nucleic acid:protein ratio (Skjoldal 1993). A food chain producing a loss equal to the input in a P-limited system may therefore in principle be different, possibly shorter, than would be the case under N-limitation. Bacteria with a low N:P value (Vadstein et al. 1988) invading sinking particles could have a similar effect. An important consequence of these considerations is that the equilibrium total concentration of biologically available phosphate (sum of all pools) in the photic zone is a combined function of the rate of nutrient input from deep waters, and the trophic position of organisms producing P-containing material re-exported to the aphotic zone. If there are many trophic links from the mineral nutrient consumers to the exporting organisms, equilibrium would correspond to a long food chain and a relatively high total $\mathrm{P}$ in the photic zone. If small organisms cause the export of P-containing material, a food chain with only small organisms can balance the input. In Villefranche Bay, we found roughly $2 / 3$ of the particulate-P $<100 \mu \mathrm{m}$ to be in size fractions $<10 \mu \mathrm{m}$ (Fig. 1). Studies of size-distributions of uptake and redistribution of radioactively labelled orthophosphate in Villefranche Bay (Dolan et al. in press) have indicated a dominance of P-uptake in the small $(<5 \mu \mathrm{m})$ and predominantly in the bacterial $(<1 \mu \mathrm{m})$ size fraction in summer, as well as a regeneration of most of the phosphate without transfer through larger sizefractions. Primary phosphate uptake in larger size classes $(>10 \mu \mathrm{m})$ increased as the thermocline eroded during autumn.

\section{CONSEQUENCES FOR C STORAGE IN DEEP WATERS BY SINKING PARTICLES}

Storage of $\mathrm{C}$ in deep waters is a question of the concentration of $\mathrm{C}$ compounds found in deep waters, not the rate at which it is exchanged between surface and deep waters. Conditions under which the system of sinking organic particles will lead to high deep water concentrations of $\mathrm{C}$ are: (1) a high $\mathrm{C}$ : nutrient ratio in

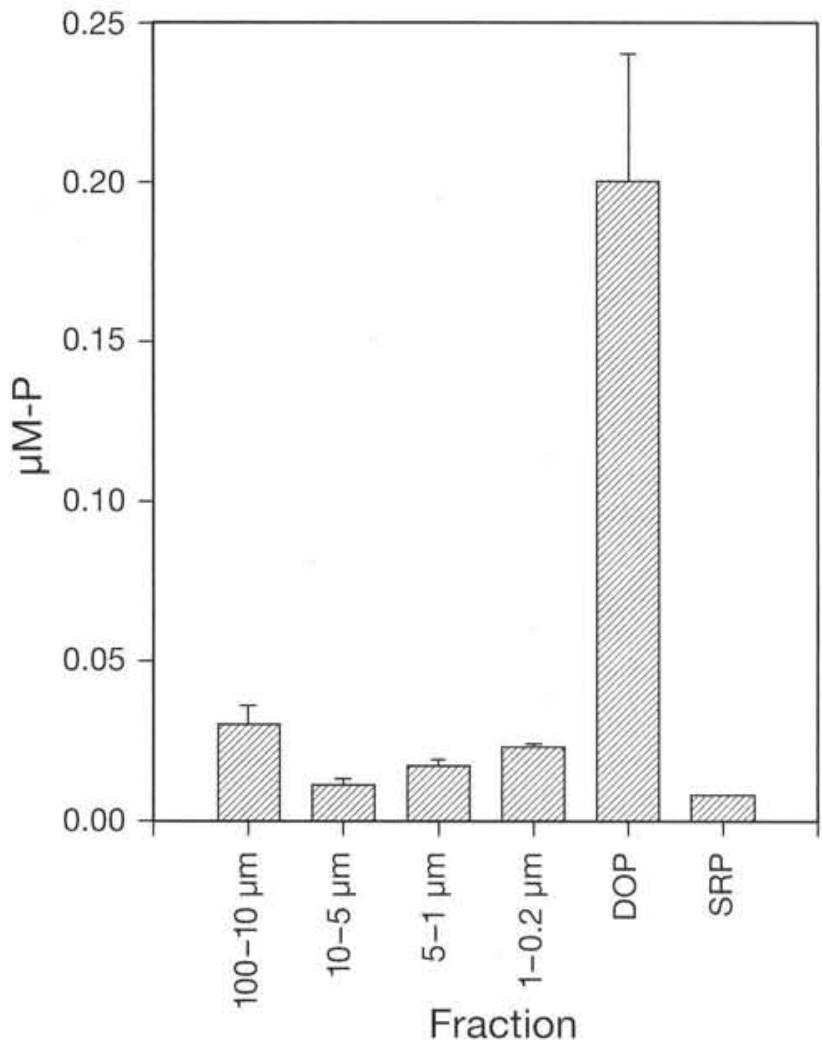

Fig. 1. Distribution of $\mathrm{P}$ at $5 \mathrm{~m}$ in Villefranche Bay, France, June 28, 1993. Determinations of organic P based on wet oxidation with persulphate, particulate fractions from sizefractionation on polycarbonate filter and orthophosphate (below detection limit of chemical analysis) estimated from uptake kinetics as described by Thingstad et al. (1993)

the sinking particles, (2) a good separation in depth between the release of the limiting nutrient and the release of $\mathrm{C}$ to dissolved forms, and (3) a high amount of the limiting nutrient (integrated over the water column) (Thingstad 1993). The principle of spatial separation of $\mathrm{C}$ and mineral nutrient caused by sinking particles is illustrated in Fig. 2. Since the advective or turbulent processes transporting limiting mineral nutrients towards the photic zone will also transport dissolved C, it is intuitively clear that releasing the limiting nutrient in the more turbulent waters close to the photic zone, while passing the $\mathrm{C}$ on to deep waters, will provide a more efficient storage mechanism than one where the mineral nutrient follows the $\mathrm{C}$ into the deep waters. The evidence is that $\mathrm{P}$ is released faster and is more rapidly regenerated than both $\mathrm{N}$ and $\mathrm{C}$ (Bishop et al. 1977, Martin et al. 1979, Garber 1984). If this is true, and sinking particles constitute the main mechanism of nutrient export from the photic zone, one would theoretically expect a P-limited system to be more efficient in $\mathrm{C}$ storage than those where $\mathrm{N}$ is the limiting nutrient. 


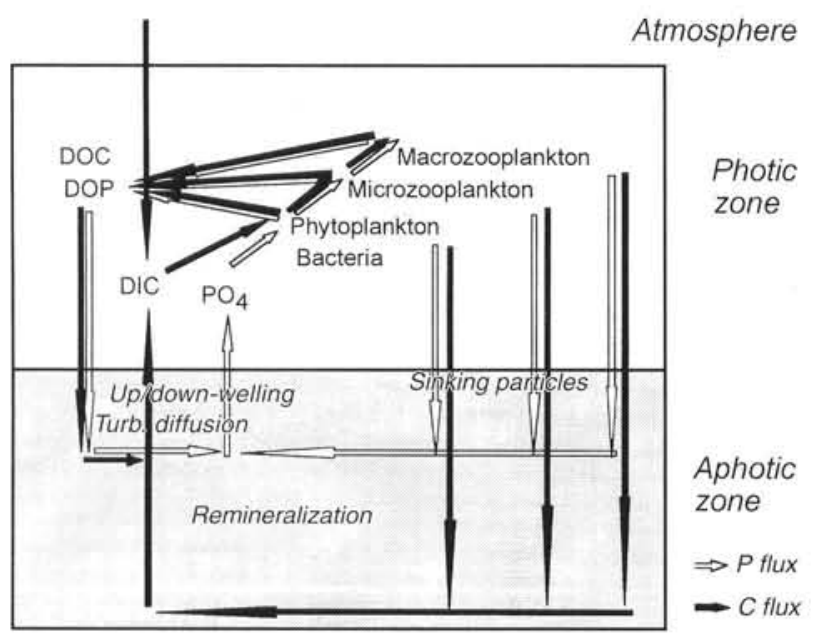

Fig. 2. Illustration of a conceptual model suggesting an alternative functioning of the photic zone food web in phosphorus cycling: in addition to transforming imported 'new' phosphorus into sinking particles, it is also transformed into DOP re-exported by the processes of turbulent diffusion and downwelling. Spatial separation of C and P in deep waters is suggested to occur primarily for particle transport

\section{POTENTIAL CONSEQUENCES OF HIGH DOP CONCENTRATIONS}

Measurements in Villefranche Bay indicate that most of the $\mathrm{P}$ in the photic zone is in the form of dissolved organic compounds (DOP; Fig. 1). Our value is slightly higher than the $0.13 \mu \mathrm{mol} \mathrm{kg}{ }^{-1}$ at $5 \mathrm{~m}$ in the western basin reported by Bethoux et al. (1992). This partitioning of $\mathrm{P}$ with the major part in the DOP-pool corresponds to the situation found in the P-limited brackish layers of Norwegian fjords (Thingstad et al. 1993). As pointed out for an $\mathrm{N}$-limited system by Legendre \& Gosselin (1989), high concentrations of the limiting nutrient in dissolved organic forms in the photic zone opens the way to a reinterpretation of how the photic zone food web functions in $\mathrm{C}$ and mineral cycling. The interesting aspects occur if the dissolved organic forms of the limiting nutrient have a life time comparable to the characteristic time scale for vertical transport of dissolved compounds between the photic and aphotic zones. This would create a concentration gradient allowing net transport of dissolved organic compounds downwards into deep waters where they are remineralized to inorganic forms. The inorganic forms can then be transported upwards again by diffusive and advective processes. If, on the other hand, the life time is much shorter than the characteristic time scales of vertical transport, the dissolved compounds will be remineralized in the photic zone, while if the life time is much longer, the dissolved organic compounds may only represent a large pool of recalcitrant, biologically unavailable nutrient of uniform concentration. Supporting evidence for a decay rate for DOP within the interesting order of magnitude is found in the observation of Bethoux et al. (1992) of a decreasing concentration with depth in the western Mediterranean basin (from $0.13 \mu \mathrm{mol} \mathrm{kg}{ }^{-1}$ at $5 \mathrm{~m}$ to $0.036 \mu \mathrm{mol} \mathrm{kg}^{-1}$ in deep waters). Interestingly, Najjar et al. (1992) have been able to improve the correspondence between model prediction and the observed phosphate distribution in global circulation models by incorporating DOP production and decay in the model description.

If the main export of $\mathrm{P}$ occurs via dissolved organic forms, the equilibrium conditions for the photic zone food web would be that the organisms present in the food chain would have to produce DOP which is exported at a rate equal to the import of biologically available forms of P. A main difference from the traditional concept of particle export would be that the linkage between export and organism size disappears. Since particles have to be of a certain size in order to sink, either (1) primary production has to be based on large phytoplankton, (2) the food chain has to extend to large predatory organisms, or (3) physical agglomeration processes must transform small particles into larger ones for export by sinking particles to occur. Since DOP can in principle be produced as efficiently by small as by large organisms, it is entirely possible for a food web containing only small organisms to have a DOP export balancing DIP import, even when the limiting nutrient is imported at significant rates.

Nutrient export from the photic zone in the form of DOP would also have important consequences for the vertical transport of carbon. The C:P ratio of the DOP itself is unknown and may in principle be either higher or lower than the Redfield ratio of 106:1 (molar). An idea of the ratio between $\mathrm{C}$ and $\mathrm{P}$ in vertical transport of total dissolved organic compounds may be obtained using the DOC values given by Copin-Montégut \& Avril (1993). They have, on the basis of annual changes in DOC profiles, suggested that the carbon transfer to the deep Mediterranean waters as DOC by diffusion and deep water formation is more than twice the amount measured in sediment traps. Taking the difference between their maximum autumn values and the deep water concentrations, the 'degradable' part of the DOC in surface waters in autumn would be around $0.4 \mathrm{mg} \mathrm{C}^{-1}\left(\approx 33 \mu \mathrm{mol} \mathrm{C}{ }^{-1}\right)$. In comparison, the DOP values given by Bethoux et al. (1992) give a DOP difference between surface and deep waters of $0.09 \mu \mathrm{mol} \mathrm{P}^{-1}$, i.e. a molar C:P ratio of around 367. With such a high C:P ratio, more then 3 times as much carbon is transported to deep waters per $\mathrm{P}$ atom consumed as would be in transport by particles with a C:P ratio of around 106. This apparent efficiency relative to 
downwards $\mathrm{C}$ transport by POM may, however, be counteracted by the absence of a mechanism allowing physical separation in depth of $\mathrm{C}$ and $\mathrm{P}$ transported in DOM. Copin-Montégut \& Avril (1993) suggested that the rate of DOC transport of $\mathrm{C}$ to deep Mediterranean waters is twice as high as the transport by sinking particles. Since, however, C storage is a concentration rather than a rate phenomenon, the extension of this conclusion to the relative importance of DOC and POC on $\mathrm{C}$ sequestering in the Mediterranean is not immediately obvious.

The suggested accumulation of degradable DOC in surface waters raises 2 main questions, one concerning where in the food web the DOC is produced, the other concerning how bacterial degradation of the material is controlled. Excretion of DOC apparently occurs both from phytoplankton (Myklestad et al. 1989) and from zooplankton (Jumars et al. 1989), and some estimates of bacterial cell lysis by viral infection (Bratbak et al. 1992) give very high release rates for dissolved organic compounds. DOP release specifically in the form of DNA during nanoflagellate predation on bacteria has been shown by Turk et al. (1992). If one considers the observations within the confinement of a simple 2-species model of phytoplanktonbacterial competition, a hypothesis attributing DOC accumulation to P-limitation of bacterial growth rate creates yet another of the apparent paradoxes in microbial food web dynamics; as judged both from theoretical considerations (Jumars et al. 1993) and from measurement of orthophosphate uptake kinetics (Thingstad et al. 1993), the bacteria with their small size and favorable surface:volume ratio probably have the highest affinity for dissolved orthophosphate. The bacteria should therefore presumably outcompete the phytoplankton, thereby reducing phytoplankton biomass until the autochthonous DOC production falls to a level where the bacteria become $\mathrm{C}$-limited. This type of mechanism has been invoked to explain algal-bacterial relationships in chemostats by Bratbak \& Thingstad (1985). As pointed out by these authors, this model creates another potential paradox related to phytoplankton physiology: do nutrient-limited phytoplankton stimulate their bacterial competitors for nutrients by producing degradable DOC? Using a slightly more complex model involving bacterial predators, one can show that under the combination of low bacterial growth rate caused by phosphate competition from phytoplankton with low bacterial biomass caused by predation, DOC degradation can be severely restricted (Thingstad \& Pengerud 1985). This type of 3 species interaction has been shown experimentally to virtually inhibit glucose degradation in chemostat cultures (Pengerud et al. 1987). If viruses turn out to be as important as some data seem to suggest (Bratbak et al. 1992), viral lysis should add significantly to protozoan bacterivory in the control of bacterial biomass. If such a combined hypothesis explains the net accumulation of degradable DOC in the photic zone, it would be a case illustrating how the functioning of microbial food webs cannot be understood from models considering 'topdown' or 'bottom-up' control mechanisms in isolation.

\section{CONCLUSION}

There seems to be a tendency toward general agreement in the literature that stratified, nutrient-poor, pelagic systems develop 'microbial' food webs. This contrasts with turbulent, nutrient-rich environments where 'classical' food chains with primary production typically based on diatoms develop (Lenz 1992, Riegman et al. 1993). We have summarized information adding details to this picture by suggesting that, during summer stratification, the microbial food web in Mediterranean surface waters is characterized by (1) P-limitation of both phytoplankton and bacteria, (2) high surface concentrations and vertically decreasing gradients of DOP and DOC, (3) restricted bacterial degradation of DOC due to a combination of Plimitation and predatory (and viral?) control, and (4) organisms in small size fractions, particularly bacteria, dominating the regenerative P-cycle. These observations all fit together in a scenario where the food web in the photic zone transforms imported orthophosphate to DOP of limited biological availability. The 'loss' of orthophosphate to such forms of DOP would decrease the total content of 'biologically available $\mathrm{P}^{\prime}$ in the photic zone, presumably leading to short food chains and more pronounced 'physiological' P-limitation, and restricting the bacterial consumption of otherwise degradable DOC. Vertical diffusion and water exchange during winter deep water formation apparently carries the accumulated DOC and DOP to deep waters where degradation is possible due to long residence time and the absence of phosphate competition from light-requiring autotrophs. Such a system may of course function in parallel with a system transforming imported phosphate into sinking particles. Thingstad \& Sakshaug (1990) used a concept of a dual food chain based on small and large phytoplankton, where the first group is rapidly growing and rapidly grazed, while the other group has the potential to respond to nutrient pulses. Expanding this with a 'microbial loop' from DOC to bacteria to bacterial predators, one obtains something like the food web sketched in Fig. 3 with 3 entrances of the mineral nutrient: bacteria, small phytoplankton and large phytoplankton. The 'microbial' type food web in the left part 


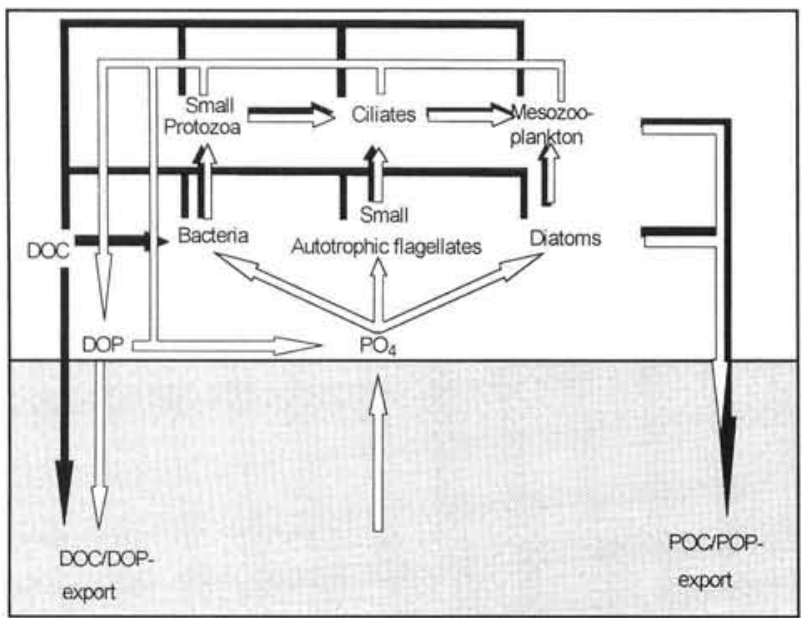

Fig. 3. Expanded view of the photic zone food web of Fig. 2 and its 2 suggested aspects: to the left a 'microbial' food web combining nutrient competition and predation as controlling factors for bacterial degradation of DOC with DOC/DOPnet accumulation and export as a consequence; to the right a 'classical' food chain developing under conditions of increased nutrient input and generating sedimenting particles

of Fig. 3 includes the competition/predation control of bacteria promoting DOC accumulation at low content of total available phosphorus. At higher total P, the 'classical' food chain from diatoms to mesozooplankton to the right in Fig. 3 would be established. This concept allows for spatial separation with the 'classical' food chain converting nutrient pulses into sinking particles at the nutricline, in upwelling areas, and in frontal zones, leaving the 'microbial' part to dominate in stable and oligotrophic systems. Such a concept seems to contain the essential elements required for describing the dynamics of vertical nutrient transfer and chlorophyll distributions as they have been observed in a warm-core eddy in the eastern Mediterrranean (Krom et al. 1992). There is apparently also temporal separation of the 2 modes of operation of the photic zone food web in the Mediterranean, with winter situations characterized by primary nutrient uptake into organisms in larger size classes (Dolan et al. in press) and a maximum in sedimentation rate in late winterearly spring (Fowler et al. 1991). The summer situation suggested above, with dominance of small organisms, and with $\mathrm{C}$ and $\mathrm{P}$ being 'stored' in the forms of DOC and DOP, coincides with the seasonal minimum in sedimentation (Fowler et al. 1991).

In other geographical areas of the world's oceans without deep water formation, or in places like the North Atlantic where light limitation may be speculated to release mineral nutrient limitation and allow degradation of dissolved organic matter before winter deep water formation occurs, the proposed mechanism of $\mathrm{C}$ sequestration by DOC accumulation and transport to deep waters presumably functions less efficiently.

The suggested scenario does not provide any immediate answer to the central question as to why the Mediterranean is shifted towards P- rather than Nlimitation. One line of speculation could be based on the idea that small organisms bind more $\mathrm{P}$ than $\mathrm{N}$ in biomass, which would make 'microbial'-dominated ecosystems relatively more P-demanding (Skjoldal 1993), another that the 'loss' of P to DOP perhaps is larger than that of $\mathrm{N}$ to DON. Neither of these seem, however, to provide any immediate explanation for the observed elevated values of the deep water N:P ratio, nor is there any immediate clue as to why these mechanisms should be of particular importance in the Mediterranean.

The functioning of the microbial food web in the surface water suggested here is fundamentally different from a traditional picture with 'new' production based on nitrate being re-exported as sinking particles, and with a bacterial population assumed to be limited by the availability of $\mathrm{C}$ substrates. It also adds a new aspect to the 'microbial loop' question raised by Azam et al. (1983) concerning the role of microorganisms in incorporating DOC into the particulate food chain. If the suggested concept is correct, processes to which relatively little attention has so far been paid, such as the extracellular enzymatic hydrolysis of macromolecular DOP, the microbial processes leading to differential release of nutrients and $\mathrm{C}$ from sinking particles (e.g. Smith et al. 1992), and the combined effect of nutrient and predation control of bacteria (Thingstad \& Pengerud 1985), become key processes in the regulation of the planktonic food web and its biogeochemical consequences.

Acknowledgements. This work was supported by the Commission of the European Communities through MAST II Mediterranean Targeted Project (contract MAS 2 - CT93-0063, 'Medipelagos'), the Norwegian Research Council and the Centre National de Recherche Scientifique, U RA 716 (France). The ideas presented here have been developed through numerous discussions with partners within the 'Medipelagos' project.

\section{LITERATURE CITED}

Azam, F., Fenchel, T., Field, J. G., Gray, J. S., Meyer-Reil, L. A., Thingstad, T. F. (1983). The ecological role of water-column microbes in the sea. Mar. Ecol. Prog. Ser. 10: $257-263$

Berland, B. R., Bonin, D. J., Maestrini, S. Y. (1980). Azote ou phosphore? Considérations sur le 'paradoxe nutritionnel' de la mer méditerranée. Oceanol. Acta 3: 135-142

Bethoux, J. P., Copin-Montegut, G. (1986). Biological fixation of atmospheric nitrogen in the Mediterranean Sea. Limnol. Oceanogr. 31: 1353-1358

Bethoux, J. P., Morin, P., Madec, C., Gentili, B. (1992). Phos- 
phorus and nitrogen behavior in the Mediterranean Sea. Deep Sea Res. 39: 1641-1654

Bishop, J. K. B., Collier, R. W., Ketten, D. R., Edmond, J. M. (1977). The chemistry, biology, and vertical flux of particulate matter from the upper $400 \mathrm{~m}$ of the equatorial Atlantic ocean. Deep Sea Res. 24: 511-548

Bratbak, G., Thingstad, T. F. (1985). Phytoplankton-bacteria interactions: an apparent paradox? Analysis of a model system with both competition and commensalism. Mar. Ecol. Prog. Ser. 25: 23-30

Bratbak, G., Heldal, M., Thingstad, T. F., Riemann, B., Haslund, O. H. (1992). Incorporation of viruses into the budget of microbial C-transfer. A first approach. Mar. Ecol. Prog. Ser. 83: 273-280

Codispoti, L. A. (1989). Phosphorus vs, nitrogen limitation of new (export) production. In: Berger, W. H., Smetacek, V. S., Wefer, G. (eds.) Productivity of the ocean, present and past. Wiley, Chichester, p. 377-394

Copin-Montégut, G., Avril, B. (1993). Vertical distribution and temporal variation of dissolved organic carbon in the North-Western Mediterranean Sea. Deep-Sea Res. 40: 1963-1972

Dahl, E., Danielssen, D. S., Semb, A., Tangen, K. (1987). Precipitation and run-off as fertilizer to a Gyrodinium aureolum Hulburt bloom. Rapp. P.-v. Cons. int. Explor. Mer 187: $66-73$

Dolan, J. R., Thingstad, T. F., Rassoulzadegan, F. (in press), Phosphate transfer between microbial size-fractions in Villefranche Bay (N.W. Mediterranean Sea), France, in autumn 1992. Ophelia

Dugdale, R. C., Goering, J. J. (1967). Uptake of new and regenerated forms of nitrogen in primary productivity. Limnol. Oceanogr. 12: 196-206

Fiala, M., Cahet, G., Jacques, G., Neveux, J., Panouse, M. (1976). Fertilization de communautés phytoplanctoniques. I. Cas d'un milieu oligotrophique: Mediterranée nordoccidentale. J. exp. mar. Biol. Ecol. 24: 151-163

Fowler, S. W., Small, L. F., La Rosa, J. (1991). Seasonal particulate carbon flux in the coastal northwestern Mediterranean Sea, and the role of zooplankton fecal matter. Oceanol. Acta 14: 77-85

Garber, J. H. (1984). Laboratory study of nitrogen and phosphorus remineralization during the decomposition of coastal plankton and seston. Estuar. coast. Shelf. Sci. 18: 685-702

Goldman, J. C., McCarthy, J. J., Peavey, D. G. (1979). Growth rate influence on the chemical composition of phytoplankton in oceanic waters. Nature 279: 210-215

Hickel, W., Mangelsdorf, P., Berg, J. (1993). The human impact in the German Bight: eutrophication during three decades (1962-1991). Helgoländer Meeresunters. 47: 243-263

Jacques, G., Cahet, G., Fiala, M., Panouse, M. (1973). Enrichissement de communautés phytoplanctoniques néritiques de Méditerranée nord occidentale. J. exp. mar. Biol. Ecol. 11: 287-295

Jumars, P. A., Deming, J. W., Hill, P. S., Karp-Boss, L., Dade, W. B. (1993). Physical constraints on marine osmotrophy in an optimal for aging context. Mar. Microb. Food Webs 7: $121-161$

Jumars, P. A., Penry, D. L., Baross, J. A., Perry, M. J., Frost, B. W. (1989). Closing the microbial loop, dissolved carbon pathway to heterotrophic bacteria from incomplete ingestion, digestion and adsorption in animals. Deep Sea Res. 36: $483-495$

Krom, M. D., Kress, N., Brenner, S. (1991). Phosphorus limitation of primary productivity in the eastern Mediterranean Sea. Limnol. Oceanogr. 36: 424-432

Krom, M. D., Brenner, S., Kress, N., Neori, A., Gordon, L. I.
(1992). Nutrient dynamics and new production in a warmcore eddy from the Eastern Mediterran. Deep Sea Res. 39: $467-480$

Legendre, L., Gosselin, M. (1989). New production and export of organic matter to the deep ocean: consequences of some recent discoveries. Limnol. Oceanogr. 34: 1374-1380

Lenz, J. (1992). Microbial loop, microbial food web and classical food chain: their significance in pelagic marine ecosystems. Arch. Hydrobiol. Beih. 37: 265-278

Lignell, R., Kaitala, S., Kuosa, H. (1992). Factors controlling phyto- and bacterioplankton in late spring on a salinity gradient in the northern Baltic. Mar. Ecol. Prog. Ser. 84: 121-131

Martin, J. H., Knauer, G. A., Bruland, K. (1979). Fluxes of particulate carbon, nitrogen and phosphorus in the upper water column of the northeast Pacific. Deep Sea Res. 26: 97-108

Myklestad, S., Holm-Hansen, O., Vårum, K. M., Volcani, B. E. (1989). Rate of release of extracellular amino acids and carbohydrates from the marine diatom Chaetocheros affinis. J. Plankton Res. 11: 763-773

McGill, D. A (1965). The relative supplies of phosphate, nitrate and silicate in the mediterranean sea. Rapp. P.-v. Réun. Comm. int. Explor. scient. Mer Méditerr. 18(3): 737-744

Najjar, R. G., Sarmiento, J. L., Toggweiler, J. R. (1992). Downward transport and fate of organic matter in the ocean: simulations with a general circulation model. Global biogeochem. Cycles 6: 45-76

Owens, N. J. P., Rees, A. P., Woodward, E. M. S., Mantoura, R. F. C. (1989). Size-fractionated primary production and nitrogen assimilation in the northwest Mediterranean Sea during January 1989. In: Martin, J. M., Barth, H. (eds.) EROS 2000 (European river-ocean system), Project workshop. Comm. Eur. Communities Water Pollut. Res. Rep., Paris, p. 126-134

Parslow, J. S., Harrison, P. J., Thompson, P. A. (1984). Saturated uptake kinetics: transient response of the marine diatom Thalassiosira pseudonana to ammonium, nitrate, silicate and phosphate starvation. Mar. Biol. 83: 51-59

Pengerud, B., Skjoldal, E. F., Thingstad, T. F. (1987). The reciprocal interaction between degradation of glucose and ecosystem structure. Studies in mixed chemostat cultures of marine bacteria, algae, and bacterivorous nanoflagellates. Mar. Ecol. Prog. Ser. 35: 111-117

Perry, M. J. (1972). Alkaline phosphatase activity in subtropical Central Pacific waters using a sensitive fluorometric method. Mar. Biol. 15: 113-119

Paasche, E., Erga, S. R. (1988). Phosphorus and nitrogen limitation of phytoplankton in the inner Oslofjord (Norway) Sarsia 93: 229-243

Richards, F. A. (1958). Dissolved silicate and related properties of some western North Atlantic and Caribbean waters. J. mar. Res. 17: 449-465

Riegman, R., Kuipers, B. R., Noordeloos, A. A. M., Witte, H. J. (1993). Size-differential control of phytoplankton and the structure of plankton communities. Neth. J. Sea Res. 31: 255-265

Sakshaug, E., Holm-Hansen, O. (1977). Chemical composition of Skeletonema costatum (Grev.) Cleve and Pavlova (Monochrysis) lutheri (Droop) Green as a function of nitrate-, phosphate-, and iron-limited growth. J. exp. mar. biol. Ecol. 29: 1-34

Skjoldal, H. R. (1993). Eutrophication and algal growth in the North Sea. In: Della Croce, N. F. R. (ed.) Symposium Mediterranean Seas 2000. Univ. of Genova, Instituto Scienze Ambientali Marine - Santa Margherita Ligure, p. $445-478$ 
Smith, D. C., Simon, M., Alldredge, A. L., Azam, F. (1992). Intense hydrolytic enzyme activity on marine aggregates and implications for rapid particle dissolution. Nature 359: $139-142$

Thingstad, T. F. (1993). Microbial processes and the biological carbon pump. In: Evans, G. T., Fasham, M. J. R. (eds.) Towards a model of ocean biogeochemical processes. Springer-Verlag, Berlin, p. 193-208

Thingstad, T. F., Pengerud, B. (1985). Fate and effect of allochthonous organic material in aquatic microbial ecosystems. An analysis based on chemostat theory. Mar. Ecol. Prog. Ser. 21: 47-62

Thingstad, T. F., Sakshaug, E. (1990). Control of phytoplankton growth in nutrient recycling ecosystems. Theory and terminology. Mar. Ecol. Prog. Ser. 63: 261-272

Thingstad, T. F., Skjoldal, E. F,, Bohne, R. A.(1993). Phos-

This review was submitted to the editor phorus cycling and algal-bacterial competition in Sandsfjord, western Norway. Mar. Ecol. Prog. Ser. 99: 239-259

Turk, V., Rhenstam, A.-S., Lundberg, E., Hagström, Å. (1992). Release of bacterial DNA by marine nanoflagellates, an intermediate step in phosphorus regeneration. Appl. environ. Microbiol. 58: 3744-3750

Vadstein, O., Jensen, A., Olsen, Y., Reinertsen, H. (1988). Growth and phosphorus status of limnetic phytoplankton and bacteria. Limnol. Oceanogr. 33: 489-503

Vukadin, I., Stojanoski, L. (1976). C:N:Si:P ratio in the waters of the middle and Adriatic. Rapp. P.-v. Réun. Comm. int. Explor. scient. Mer Méditerr. 23(7): 41-43

Zweifel, U. L., Norrman, B., Hagström, A. (1993). Consumption dissolved organic carbon by marine bacteria and demand for inorganic nutrients. Mar. Ecol. Prog. Ser. 101: $23-32$

Manuscript first received: June 9, 1994

Revised version accepted: October 13, 1994 